\author{
Aleksander Wojciech Mikołajczak \\ Adam Mickiewicz University in Poznań \\ mikolax@amu.edu.pl \\ ORCID: 0000-0002-4495-7440
}

Data przesłania tekstu do redakcji: 15.11.2020

Data przyjęcia tekstu do druku: 12.02.2021

\title{
Rola pszczół i wosku pszczelego w tworzeniu glagolickich liter
}

\begin{abstract}
Mikołajczak Wojciech Aleksander, Rola pszczót $i$ wosku pszczelego w tworzeniu głagolickich liter (The Role of Bees and Beeswax in Creating Glagolitic Letters). "Poznańskie Studia Slawistyczne" 20. Poznań 2021. Publishing House of the Poznań Society for the Advancement of the Arts and Sciences, Adam Mickiewicz University, pp. 239-257. ISSN 2084-3011.

The article shows what role the writing instruments, in particular wax tablets, used by St. Cyril the Philosopher, could play in shaping the material form of Glagolitic writing. In this research approach, writing is treated not only as a system of abstract signs, but also as their factual figure formed by a tool on a writing material. In the case of the Glagolitic alphabet, its creation was therefore both a mental and physical process involving objects such as wax tablets. The ease of engraving the shapes of new letters on a soft surface and the possibility of repeatedly erasing them allowed Cyril to experiment with their forms without consuming valuable parchment. Therefore, this process depended mainly on the material properties of the wax produced by honeybees, which was used to cover the wooden tablets designed for writing with a stylus. In this way, these insects participated in the creation of the material dimension of Slavic writing, on a par with people who took the stick from them, choosing the wax from the hives to further process it. This proves that Cyril did not force the Glagolitic letters formed in his mind onto passive material, but that beeshaped, writing wax affordances actively cooperated in this process.
\end{abstract}

Keywords: Glagolitic; St. Cyril the Philosopher; wax tablets; writing; bees

\section{Narzędziowa perspektywa piśmienności}

Słowianie wkroczyli w okres piśmienności w IX wieku, co sprawiło, że korzystali z zastanej technologii pisma, adaptując ją do swych potrzeb (Джурова, 1997, 25). Stało się to w czasach, gdy zarówno w Bizancjum, jak i na Zachodzie nastąpiło już odejście od użytku trzcinowych kalamo-

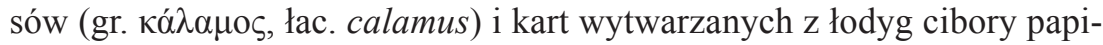
rusowej (łac. Cyperus papirus L.) (Dahl, 1965, 29-32). Przemiany te sprawiły, że ukształtowana w antyku technologia pisma uległa transformacji, 
otwierając nowy rozdział europejskiej piśmienności. Jej słowiański wątek wplótł się wtedy w rzeczową osnowę pisma, jaką stanowiły przybory wytwarzane głównie z surowców pochodzenia zwierzęcego: pergamin produkowany ze skór, pióra z ptasich lotek, a także tabliczki pokrywane pszczelim woskiem.

Celem niniejszego artykułu jest zwrócenie uwagi na ich rolę w formowaniu słowiańskiej piśmienności, szczególnie zaś wosku, który pośród innych przyborów i materiałów piśmiennych nie był traktowany jako czynnik sprawczy słowiańskiego pisma (Pietkiewicz, 2015, 176-221). Tymczasem wydaje się on ważny jako narzędziowy mediator w tym złożonym procesie angażującym zarówno ludzkich, jak i niebędących ludźmi realizatorów. Powstanie alfabetu głagolickiego nie było bowiem tylko tworem umysłu czystą ideą zrodzoną w myśli Cyryla Filozofa jako jego twórcy. Podobnie w wypadku cyrylicy nie była nią tylko mentalna wizja pisma powstała, jak się sądzi, w świadomości uczniów i następców Braci Sołuńskich (Horodyński, 1951, 18). Ukształtowanie obu tych pism nie mogło się bowiem dokonać bez udziału konkretnych przyborów i materiałów piśmiennych, właśnie takich jak wosk, za pomocą których owe abstrakcyjne idee zostały rzeczowo zmaterializowane.

Przedmiotem badań będzie zatem kreacja głagolickiego pisma jako proces uwarunkowany zarówno kognitywnie, jak i ontologicznie, który objaśnić można za pomocą kategorii antropologiczno-filozoficznych. Jest to zupełnie inne podejście niż dominujące w głównym nurcie paleoslawistycznych badań nad genezą głagolicy, gdyż nie zajmuje się kwestią pochodzenia tego alfabetu, jego graficzną symboliką, ani też semiotyczną pragmatyką. Istotą tego artykułu nie jest więc wzbogacenie dociekań nad tymi kwestiami o nowe fakty lub interpretacje. Chodzi w nim natomiast o zwrócenie uwagi na możliwość osadzenia refleksji nad słowiańską piśmiennością w nowej dlań perspektywie filozofii kultury. Pozwala ona przyjrzeć się procesowi kreacji głagolicy zarówno w jego antropologicznym, jak i ontologicznym wymiarze, co może poszerzyć historyczno-semiotyczne spojrzenie na ten problem.

Podejmowany temat wart jest uwagi nie tylko ze względu na jego slawistyczne znaczenie, lecz także przez odniesienia do antropologii pisma. Wynika to z roli odgrywanej przez narzędzia w procesie przemiany myśli w tekst wyrażony w określonym języku, skonkretyzowany w danej grafii 
i finalnie rzeczowo upostaciowiony. Współczesne badania nad pismem coraz częściej zwracają się ku takiemu ujęciu, czego przykładem może być monografia Keith'a Houstona (2017), skupiająca się na rzeczowych funkcjonalnościach książki. Ujawnia się w tym spojrzenie na pismo wykraczające poza pojmowanie go tylko jako wytworu kultury symbolicznej, czego świadomi byli już badacze pism starożytnego wschodu, traktujący je w kategoriach archeologicznych artefaktów (Breasted, 1916, 237-239).

Problem polega na tym, by odpowiednio wyważyć obie te perspektywy, nie odżegnując się ani od symbolicznego, ani też przedmiotowego wymiaru grafii. Dlatego w moim artykule staram się połączyć oba te ujęcia, odwołując się zarówno do procesów kognitywnych, jak i wytwórczych, które wpłynęły na uksztaltowanie się słowiańskiego pisma. Wymaga to jednak weryfikacji podejść badawczych, które pomijały dotąd piśmienny splot ludzkich kompetencji z przedmiotowymi afordancjami rzeczy, czyli zdolnościami przedmiotów do oddziaływania na inne obiekty i ludzi (Norman, 2018, 29-30).

\section{Ku nowej metodologii}

Chociaż czynność pisania angażuje zarówno ludzki umysł, jak i ciało, to jednak fizyczne komponenty tego procesu postrzegane bywają zazwyczaj jako wtórne w stosunku do jego mentalnych i noetycznych aspektów. Samo pismo dość wcześnie stało się domeną badań paleograficznych, lecz te skupiają się przede wszystkim na jego pochodzeniu i formie, w mniejszym zaś zakresie na technologii (Wójtowicz, 2000). Podobnie kodykologia, choć skoncentrowana na materialnym wymiarze piśmienności, długo nie wychodziła poza swego rodzaju ,,antykwaryczny” opis badanych artefaktów (Dain, 1949). W obu podejściach sam proces pisania nieczęsto więc bywał tematem odrębnych dociekań, aż do zaistnienia na przełomie XVIII i XIX wieku tak zwanej „kwestii homerowej”, która wywołała dyskusję nad przejściem w cywilizacji greckiej od twórczości oralnej do piśmiennej (Wolf, 1795). Zaczęto wówczas zauważać, że użytek pisma wpływał na literacki kształt tekstu, jednak i wówczas postrzegano to głównie w kategoriach filologicznych, nie wiążąc z rzeczowymi właściwościami oraz funkcjami przyborów piśmiennych (Jansen, 1980). 
Ujęcia te pomijały zatem procesualny charakter pisania i umniejszały jego materialny wymiar, redukując funkcję narzędzi do utrwalania kształtowanych w umyśle wypowiedzi. Źródła tego podejścia szukać należy w Arystotelesowskiej teorii hylemorfizmu, która w dużej mierze uformowała zachodnie rozumienie rzeczywistości. Koncepcja ta najogólniej zakłada, że każda substancja jest bytem złożonym $\mathrm{z}$ dwu związanych ze sobą składników formy (morphe) oraz materii (hyle) (Krąpiec, 1968, 55-65). Zdaniem Tima Ingolda $\mathrm{z}$ czasem ukształtowała ona asymetryczny model tworzenia rzeczy, albowiem: „Formę zaczęto postrzegać jako narzuconą przez jakiegoś zewnętrznego sprawcę, w którego umyśle istnieje określony projekt, podczas gdy materia, pojmowana jako bierna i bezwładna, stała się tym, na co projekt ów był narzucany" (Ingold, 2018, 123).

W poniższych rozważaniach chciałbym odejść od takiego postrzegania przyborów do pisania, starając się ukazać ich aktywny wpływ na słowiańską piśmienność oraz na jej wybitnie procesualny charakter. Wymaga to zmiany perspektywy poznawczej, która nie koncentruje się w tym wypadku na samych ludziach, ani też na rzeczach, lecz na dynamicznie łączących je relacjach. W centrum tych relacji znajduje się bowiem Gadamerowska kategoria doświadczenia (Gadamer, 1993, 324), w którym dokonuje się synteza ontycznego i noetycznego, czyli wzajemnego odziaływania na siebie afordancji rzeczy i użytkowych kompetencji ludzi. Tego rodzaju doświadczenie ma zawsze, jak zauważa Zofia Rosińska, charakter kulturowy:

Nie ma bowiem człowieka bez kultury, podobnie jak nie ma kultury bez człowieka. Aby doświadczenie mogło być przedmiotem badania [...], musi być wyrażone, czyli upublicznione. Nie mamy bezpośredniego dostępu do wewnętrznego doświadczenia człowieka. I tylko wtedy, kiedy jest ono wyrażone - słowem, dźwiękiem czy gestem stanowi dokument kulturowy (Rosińska, 2020, 8).

Na tym właśnie polega clou proponowanego tutaj podejścia, gdyż gest pisarski staje się w nim zewnętrznym wyrazem doświadczenia, które w swych wewnętrznych treściach odnosi się do procesu transgresji myśli ku ich zmaterializowanej w piśmie postaci. Vilém Flusser przedstawił to w następujący sposób:

Wiem, że nie mogę sprawić, aby tekst odbił moje myśli bezpośrednio. Muszę najpierw umieścić je w jednym z języków pozostających do mojej dyspozycji. Język jest me- 
diacją między moimi myślami a moim pisaniem. Bardzo dynamiczną mediacją. Moje myśli zmieniają się w próbie przystosowania ich do języka, język próbuje zaś dostosować się do moich myśli. Moje pisanie odbija język zmieniony przez moje myśli, które z kolei zmieniły język (Flusser, 2018, 307).

W modelu tym Flusser zbyt łatwo przeszedł jednak z poziomu języka na poziom pisma, nie uwzględniając zmian, jakie w przemianie myśli wywołuje gest pisarski. Nie jest on bowiem tylko prostym odbiciem języka, lecz stanowi kolejną dynamiczną mediację pomiędzy powstającym tekstem a wykorzystywanym w jego tworzeniu alfabetem, zasadami grafii, kształtem liter, a także z przyborami i materiałami. W wypadku słowiańskiej piśmienności właśnie użytek tych ostatnich sprawił, że w procesie transformacyjnej mediacji uczestniczyły także istoty ożywione - ssaki, ptaki, owady i mięczaki (atrament). Wszak to z części ich ciał oraz wydzielin pozyskiwano surowce, które nadawały konkretne właściwości wytwarzanym z nich piśmiennym utensyliom (Ingold, 2018, 17-20). Stwarza to asumpt do bliższego spojrzenia na tę urzeczowioną mediację, która niedostrzegana bywa w refleksji nad doświadczaniem naszych relacji ze zwierzętami.

Proponowana przeze mnie nowa metodologia wyrasta zatem z filozoficznych koncepcji rozwijanych w ramach tak zwanego zwrotu ontologicznego, szczególnie zaś teorii aktora sieci (actor-network teory, ANT) Bruno Latoura. Francuski antropolog i filozof nauki skupia się bowiem nie tyle na samych przedmiotach, ile na relacjach łączących je z ludźmi (Latour, 2010). Odnosząc to do problematyki pisma, nazwałbym moje podejście ontologiczno-funkcjonalnym, gdyż chcąc pokazać, czym rzeczowo były litery głagolickiego alfabetu, nie wystarczy wskazać, jak wyglądały i na jakim podłożu zostały uobecnione. Trzeba wyjaśnić, do czego w danej sytuacji służyły i w jaki sposób były użytkowane. Nie można zatem skupiać się na samych literach (a tym bardziej na ich znakowej funkcji), lecz na ontycznych związkach łączących je z posługującymi się nimi ludźmi, dla których były one rekwizytami piśmiennych praktyk. Tylko tak da się zrozumieć przedmiotowe funkcje pisma pośredniczącego między naszą cielesnością a duchowym dążeniem do ekspresji abstrakcyjnych myśli i uczuć. 


\section{Materiałowe uwarunkowania pisma}

Jeśli uznamy za Timem Ingolddem, że świat nie tyle składa się z rzeczy, ile z materiałów, które podlegają heraklitejskiemu prawu zmiany (Ingold, 2018, 5-11), to ukształtowanie się słowiańskiego pisma także uznać można za specyficzny wyraz materiałowych przemian. Oczywiście wtedy, gdy litery potraktujemy nie tylko jako semantyczne znaki, lecz także jako konkretne przedmioty sporządzone z kamienia, drewna lub metalu, albo wytworzone za pomocą ptasiego pióra na pergaminie bądź rylcem na wosku. Spojrzenie takie utrudnia jednak hylemorficzna optyka, która w istocie odbiera materiałom ich samoistność. Chociaż więc litery są zaschniętymi na karcie śladami inkaustu lub wgłębionymi w podłoże rytami, traktuje się je zwykle jako abstrakcyjne w swej istocie znaki nałożone na nośnik. Ich materiałowe uobecnienie wydaje się przez to niedostrzegalne, co - jak wykazał Gerrit Noordzij - przeczy zmysłowej naturze pisma (Noordzij, 2014, 21-32).

Tymczasem gdy odwróci się hylemorficzno-semantyczną perspektywę, pismo nie przestając pełnić znakowej funkcji, uwidacznia swą oczywistą ontologiczną naturę. Także przybory i materiały piśmienne ujawniają wówczas swe kognitywne afordancje, co pozwala traktować je jako rzeczowe mediatory pomiędzy myślą a jej materiałowym upostaciowieniem. W wypadku genezy głagolicy kieruje to uwagę ku pokrywanym

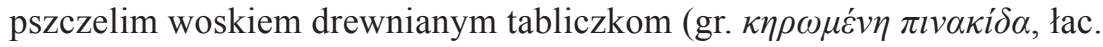
tabulae ceratae). W tej sytuacji wydają się one naturalnymi pośrednikami między mentalnym zamysłem słowiańskiego pisma a jego materiałowym spełnieniem.

By uzasadnić tę tezę, spróbuję pokazać, w jaki sposób afordancje wosku mogły oddziaływać na fizyczne kształtowanie głagolickich liter. Wymaga to wyjaśnienia kilku szczegółowych kwestii, które problematyzują to zagadnienie. Po pierwsze, należy odpowiedzieć na pytanie: jakie właściwie przesłanki przemawiają za tym, że Cyryl mógł stworzyć głagolicki alfabet, posługując się woskowymi tabliczkami i rylcem? Po wtóre, trzeba przejrzeć się, na czym polegało nadawanie woskowi własności piśmiennych przydatnych w takim przedsięwzięciu? Po trzecie, powinno się zastanowić, jaki teoretyczny model mógłby objaśnić taką narzędziową kreację nowego pisma? Wreszcie po czwarte, wypada wskazać 
przydatność takiego modelu w analizie konkretnych praktyk głagolickiej piśmienności.

Jeśli chodzi o pierwszą kwestię, to za kreatywnym użyciem przez Cyryla woskowych tabliczek przemawia kilka powodów. Jedne z nich brały się z zastanych uwarunkowań kulturowych, a także ówczesnej sytuacji geopolitycznej, inne miały charakter narzędziowy i wynikły z materiałowych właściwości wosku. Odnosząc się do tych pierwszych, należy wskazać dwie zasadnicze okoliczności. Przede wszystkim już od czasów greckich i rzymskich istniała tradycja uczenia dzieci pisania liter na woskowych tabliczkach, które w szkołach powszechnie były do tego wykorzystywane (Engelmann, 1896, 343-348). Można zatem ów uzus ekstrapolować na proces wypracowywania nowego pisma, który w pewnej mierze podobny jest do nauki pisania od postaw.

Po wtóre, należy uwzględnić trudny dostęp w IX stuleciu do takich materiałów piśmiennych jak papirus czy cenny pergamin. Brak tego pierwszego spowodowany był zmniejszeniem jego dostaw do chrześcijańskiego świata po podboju przez Arabów Egiptu w latach 640-642. Tylko sporadycznie był on używany do X wieku w kancelariach królewskich i kancelarii papieskiej (Santifaller, 1953). W wypadku zaś pergaminu jego relatywna niedostępność powodowana była wysoką ceną, wynikającą z jego pozyskiwania ze skór zwierzęcych, które poddawano skomplikowanej, specjalistycznej obróbce (Reed, 1975, 74-75).

Troska o oszczędność tego materiału nie powinna budzić zdziwienia, nawet w wypadku ćwiczenia się w piśmie o sakralnym charakterze. Wszak sacrum głagolicy nie uobecniało się w jej literach, nawet jeśli przyjmiemy hipotezę, że były one wzorowane na formie krzyża. Świętymi znaki te nie stawały się bowiem przez swój kształt, lecz przez to, że zapisane były za ich pomocą słowa Ewangelii. To zaś dokonywało się w akcie zapisywania tekstu na kartach lekcjonarza. Nic do rzeczy nie miał tu także fakt, że święci Cyryl i Metody byli bizantyjskimi arystokratami i pełnili swą posługę z polecenia cesarza, a więc mieli dostęp do pergaminu z cesarskiej kancelarii. Niefrasobliwe użycie tak cennego materiału, gdy można zastąpić go tańszym zamiennikiem, byłoby niewyobrażalnym marnotrawstwem w sytuacji, gdy w skryptoriach najmniejsze skrawki pergaminu wykorzystywano wtórnie w funkcji palimpsestów, a także jako wyklejki i wzmocnienia opraw. Wszystko to czyni mało 
prawdopodobnym pochopne wykorzystywanie go do materiałochłonnych eksperymentów z nowym pismem.

Doskonale nadawały się natomiast do tego woskowe tabliczki używane od starożytności zarówno w ówczesnej łacińskiej Europie (Bischoff, 1990, 14), jak i na obszarach, które Dimitri Obolenski określał mianem Byzantine Commonwealth (Obolenski, 1971, 281-282). Były one żywym dziedzictwem tradycji greckiej i rzymskiej piśmienności, to ona uczyniła je najbardziej rozpowszechnionymi podręcznymi przyborami piśmiennymi - głównie dlatego, że sporządzano je z tanich i łatwo dostępnych materiałów oraz z tej racji, że nadawały się do wielokrotnego użytku (możliwość wymazywania tekstu). Dzięki tym cechom stały się nieodzowne $\mathrm{w}$ rozmaitych kognitywnych zastosowaniach, nie tylko w nauce pisania, lecz także do notowania, sporządzania brudnopisów oraz korespondencji (Small, 1997, 129-133). Ujawniały się w tym afordancje pszczelego wosku, które wraz z narzędziowymi właściwościami brązowych rylców dynamizowały przemianę myśli w tekst i kształtowały krój rytych w miękkim podłożu liter.

Technologia ta znana była już na Bliskim Wschodzie od epoki brązu, o czym świadczą woskowe tabliczki datowane na około 1300 rok przed Chr., wydobyte z wraku statku, który zatonął u przylądka Uluburun na południowo-zachodnim wybrzeżu dzisiejszej Turcji (Fawcet, Zietsman, 2001, 6-20). Chociaż nie zachowała się na nich warstwa wosku, to ich kształt oraz funkcjonalność okazały się zasadniczo takie same jak w wypadku późniejszych greckich, rzymskich i bizantyjskich tego rodzaju pisarskich przyborów (Roberts, Skeat, 1982, 15). Ich konstrukcja zawsze była bowiem podporządkowywana właściwościom pszczelego wosku, którym po uprzednim stopieniu zalewano wyżłobione w drewnianych deszczułkach płyciny. Po ponownym zakrzepnięciu tego materiału zyskiwało się dogodne podłoże dla rylców (gr. $\sigma \tau \tilde{v} \lambda o \varsigma$, łac. stilus).

Wydaje się, że właśnie ta substancjalna plastyczność wosku okazała się nadzwyczaj pomocna w narodzinach słowiańskiego pisma, gdyż pozwalała Cyrylowi wielokrotnie zapisywać i ciągle poprawiać ryte na nim kształty liter. Te afordancje piśmiennego podłoża nie zostały mu jednak nadane przez ludzi. W ich kształtowaniu brali udział także uczestnicy niebędący ludźmi, czyli pszczoły miodne (Apis mellifera), owady z rodzaju Apis, rodziny pszczołowatych (Apidea) i rzędu błonkoskrzydłych. Należy 
zatem wpierw przyjrzeć się ich wkładowi w materiałowe i procesualne uwarunkowania piśmiennych praktyk.

W okresie dużych pożytków kwiatowych (w drugiej połowie wiosny i na początku lata) pszczoły wytwarzają w ulach wosk wykorzystywany do budowy komórek plastrów miodu. Substancja ta powstaje w gruczołach woskowych umieszczonych na brzusznej stronie odwłoków robotnic, które mają ich zwykle 4-7. Wydzielany przez te gruczoły wosk jako przejrzysta ciecz wypływa 30-50 kanalikami na powierzchnię oskórka i zastyga na tak zwanych lusterkach w postaci cieniutkich łuseczek o średnicy $3 \mathrm{~mm}$ i grubości 0,1 mm (Sanford, Dietz, 1976, 197-201). Następnie robotnice przeżuwają go, przez co staje się on matowy, a dodawane w tym procesie olejki pyłkowe i propolis czynią go żółtym lub brązowym.

Wytwarzanie wosku uzależnione jest od wielu okoliczności i odbywa się z różną intensywnością. By robotnice produkowały wosk, muszą być spełnione określone warunki: 1) obecność w gnieździe królowej, 2) duży procent młodych osobników, 3) temperatura w ulu 32-36 $\left.{ }^{\circ} \mathrm{C}, 4\right)$ dopływ świeżego powietrza i świeżo zbieranej karmy, 5) wolne miejsce w gnieździe na odbudowę nowych plastrów. Do wytwarzania wosku potrzebny jest pszczołom przede wszystkim pokarm węglowodanowy, czyli miód, zaś białko (pierzga) odgrywa tu mniejszą rolę. Gdy wszystkie te warunki zostaną spełnione, jedna robotnica w ciągu swojego życia jest wstanie wyprodukować ilość wosku równą połowie masy jej ciała, co sprawia, że z jednego pnia (ula) w ciągu roku można praktycznie uzyskać ok. 2-3 kg tego cennego surowca (Walewska, 1960, 255-256).

Proces wytwarzania wosku przez pszczoły jest więc złożony i zależny od okoliczności, stąd jego pasieczne pozyskiwanie wymagało wiedzy i umiejętności opiekowania się rojami. Pszczoły były hodowane przez ludzi już w okresie neolitu (najpóźniej od siódmego tysiąclecia przed Chr.), wpierw w środkowej Anatolii (Roffet-Salque, Regert, Evershed, 2015, 226-230), a później w Egipcie i w różnych regionach Europy. Na Bałkanach, gdzie pszczelarstwo już w starożytności stało się ważną dziedziną gospodarki, w średniowieczu pasieki zakładano głównie przy monasterach - nie tylko dla pozyskiwania miodu, lecz także wosku niezbędnego do wytwarzania świec na potrzeby Bożej liturgii. Jak czytamy bowiem w 134. rozdziale Świętych rytuałów i sakramentów Kościoła Arcybiskupa Symeona z Tesalonik: „Przynoszony i zapalany wosk, jako substancja 
najczystsza, oznacza naszą czystość i szczerość ofiary; wosk jako tworzywo miękkie i plastyczne, wyraża nasze posłuszeństwo i gotowość pokuty za grzeszne życie" (Nowe tablice, 2007, 43).

Jednak najczystszy wosk wykorzystywany tak w produkcji liturgicznych świec, jak i do piśmiennego użytku nie był surowym materiałem pozyskiwanym bezpośrednio od pszczół. Wymagał ingerencji ludzi, którzy jak zauważa Tom Ingold: „pływając w oceanie materiałów, oczywiście uczestniczą w ich przekształcaniu. Bardzo często przejmują więc pałeczkę od nie-ludzi: jak wtedy, gdy wybierają wosk wydzielany przez pszczoły do biedowania ścian plastrów miodu, aby potem użyć [go] do [innych celów]" (Ingold, 2018, 17-18). By uzyskać odpowiedni do pisania wosk, należało po usunięciu miodu wytopić plastry w słonecznych topiarkach. Był on zanieczyszczony wylinkami larw i resztkami pierzgi, które utrudniałyby precyzyjne prowadzenie rylca. Dlatego po ostygnięciu jeszcze czterokrotnie go podgrzewano i topiono w miedzianych kotłach w $1 / 3$ wypełnionych wodą. Używało się do tego deszczówki, gdyż jest ona pozbawiona wapnia, a więc miękka, dzięki czemu materiał nie ulega zmydleniu. Po każdym też wystygnięciu i stwardnieniu masy zbierano skrobakami osiadłe na spodzie kloca zabrudzenia, by zyskać czysty wosk (Gekeler, 2014, 13), który dopiero po tych zabiegach stanowił dobre podłoże pisarskie.

Kiedy więc Cyryl Filozof wypracowywał materialną postać głagolickiego pisma, przygotowane w ten sposób podłoże mogło być w tym znakomicie pomocne. Rylec i wosk interaktywnie uczestniczyły wówczas w procesie materialnego tworzenia znaków, co było upublicznieniem wewnętrznego doświadczenia Cyryla. Jak zauważa bowiem Remo Bodei:

Gdy ktoś pisze jakiś tekst, zawiera w nim swoje myśli, doświadczenia i uczucia. Za Diltheyem nazwiemy podmiotowość oddającą się pisaniu „duchem subiektywnym”, a jej pismo, czyli przełożenie na znaki, to jest umieszczenie na materialnym nośniku tego, co jednostka myśli, wyobraża sobie, czuje - „duchem obiektywnym” (Bodei, 2016, 76).

\section{Model epistemologiczny i model etyczny}

Fenomen głagolickiego alfabetu dobrze wpisuje się w ten mechanizm upubliczniania myśli, gdyż abstrakcyjny wytwór umysłu Cyryla Filozofa został zmaterializowany przez niego jako fonetyczny zapis słowiańskiej 
mowy. Franciszek Sławski uważał, że wśród dokonań świętych Braci Sołuńskich na rzecz misji wielkomorawskiej „na pierwszym miejscu należy postawić odważną myśl opracowania nowego alfabetu dla języka Słowian i realizację tejże myśli w postaci alfabetu zwanego głagolicą" (Sławski, 1991, 22). W stwierdzeniu tym znajduję pośrednie potwierdzenie aktu przemiany „subiektywnego ducha” Cyryla w „obiektywnego ducha” stworzonego przezeń pisma. Byłoby to więc doświadczenie gestu, który według Zofii Rosińskiej jest kreacją „,dokumentu kultury”, czyli w tym wypadku nowego słowiańskiego pisma. U Czernorizca Chrabra czytamy bowiem, że:

Dawniej Słowianie, będąc poganami, nie mieli liter, ale liczyli i wróżyli za pomocą kresek i nacięć. Przyjąwszy zaś chrzest, bez ładu usiłowali zapisywać mowę słowiańską literami łacińskimi i greckimi. Ale jak można dobrze zapisać greckimi literami takie słowa, jak Bogъ, životъ, dzělo, crıky, čaanije, širota, jadъ, ądu, junostь, językъ czy też wiele innych podobnych wyrazów. I tak było przez wiele lat (Czernorizec Chrabr, 2013, 33).

Chaos w zapisywaniu mowy słowiańskiej przed powstaniem głagolicy, a potem jego przezwyciężenie za pomocą fonetycznego zapisu głosek, bardzo tu przypomina metaforę ,zabłądzenia w lesie”, którą Vilém Flusser (2018, 80-87) posłużył się, objaśniając relacyjny mechanizm tworzenia przez ludzi rzeczy. Zachęca to do zaadaptowania tej koncepcji do potrzeb niniejszych rozważań i wykorzystania jej w celu zaproponowania teoretycznego modelu, który hipotetycznie ukazywałby proces formowania głagolicy. Odnosiłby się on najpierw do operacji kognitywnych, jakie mogły dokonywać się w umyśle Cyryla, następnie zaś do kształtowania przezeń liter na wosku za pomocą trzymanego w dłoni rylca.

Wydaje się, że model taki mógłby opierać się na schemacie następującego rozumowania: jeśli według Flussera $(2018,83)$ mogę wydostać się z gąszczu, w którym zabłądziłem, ponieważ ,umiem stanąć jakoś ponad lasem”, czyli go transcendować - tak też mogę przezwyciężyć chaos zapisu słowiańskich fonemów łacińskimi i greckimi grafemami. Potrafię tego dokonać, albowiem potrafię sproblematyzować ów bezład w swojej świadomości i określić jego przyczynę. W tym wypadku nie widzę bezładnie zapisanych słów jako wadliwych przedmiotów, lecz jako problem (w znaczeniu gr. problema - ,przeszkoda”), który stoi między mną a moim 
celem: poprawnym fonetycznym zapisem słowiańskiej mowy. Bezład zastanej grafii wymaga zatem jakiejś mojej ingerencji, abym mógł odprawiać Bożą liturgię w zrozumiałym dla Słowian języku, nie przeinaczając odczytywanych podczas jej sprawowania świętych tekstów.

Można przypuścić, że w takiej właśnie sytuacji znalazł się Cyryl u początku wielkomorawskiej misji, gdy uświadomił sobie, że ani greckie, ani też łacińskie pismo nie jest tym, czym w tych okolicznościach być powinno, czyli pismem słowiańskim. Zyskał przez to wgląd w grafię z zupełnie nowej perspektywy - jak ktoś błądzący po lesie, kto patrząc na mapę, zobaczył nagle gąszcz z góry i dzięki temu zorientował się, jak może się z niego wyplątać. W swej antropologii Flusser $(2018,84)$ nazywa to wypracowaniem modelu epistemologicznego, który umożliwia człowiekowi podejmowanie intencjonalnych działań na rzecz osiągnięcia zamierzonego celu. W wypadku projektu głagolicy model ów zasadzał się na zdobytej przez Cyryla samowiedzy o możliwości zaprojektowania liter, które w swej grafii wiernie oddawałyby dźwięki słowiańskiej mowy. Innymi słowy, posiadł on przekonanie, że można sprawić, by pismo stało się takim, jakim być powinno i jakiego potrzebował do swych celów.

Jednak posiadanie modelu epistemologicznego, a więc wyjaśniającego, nie wystarcza, by móc nagiąć rzeczywistość do postaci, jaką winna ona mieć, by spełniać pokładane w niej oczekiwania. Jest to problem, który Otl Aicher rozważał w eseju Świat jako projekt, gdzie pisał, że „osąd empiryczny nie chce ujmować przyczyn rzeczy, lecz ich cel, to, do czego się nadają. Od objaśniania przyczynowego przechodzi do finalnego. Rzeczy nie są określane przez zasadę rozumu, lecz przez zasadę celowości" (Aicher, 2016, 205). Nasza mentalna wizja tej przemiany napotyka bowiem na materialny opór substancji, których stan chcemy zmienić, by odpowiadały temu, czym być powinny, a nie są. Dotyczy to także kreacji głagolickiego alfabetu w jego rzeczowym, a więc materiałowym uobecnieniu. Ukształtowanie epistemologicznego modelu było bowiem tylko pierwszym, kognitywnym etapem wyłaniania się nowego pisma w umyśle twórcy. Drugi etap stanowiło przedmiotowe urzeczywistnienie przez Cyryla projektowego zamysłu w procesie jego materializacji za pomocą woskowych tabliczek, rylców oraz manipulującej nimi ludzkiej dłoni.

Opisując tę transformację, można odwołać się do etycznego modelu tworzenia rzeczy. Flusser objaśnia go na przykładzie gałęzi, które tworzą 
leśny gąszcz, a więc są czymś, czym z ludzkiego punktu widzenia nie powinny być, lecz są. Pozostają takimi dopóty, dopóki do lasu nie wejdzie człowiek, który „obłamuje stojącą na drodze gałąź, odwraca ją i używa jako kija do obłamywania innych gałęzi” (Flusser, 2018, 53). Przez ten kreatywny gest nadaje on gałęzi wartość, której wcześniej nie miała, czyniąc z niej kij, a więc to, czym gałąź być powinna, a nie była. Dla Flussera proces ten dokonuje się, gdyż człowiek dysponuje oboma wspomnianymi modelami: epistemologicznym i etycznym. Pozwalają mu one transcendować rzeczywistość, w wyniku czego może z bezwartościowych przedmiotów czynić użyteczne, a więc wartościowe dla niego przedmioty.

Niemniej model ten nie do końca pozwala wyjaśnić rolę afordancji przyborów i materiałów piśmiennych w ontologicznym formowaniu głagolickiego pisma. Skupiając bowiem uwagę już tylko na piśmiennym podłożu, można stwierdzić, że nie było ono w wypadku gestu pisarskiego Cyryla tylko biernym materiałem, w który wtłaczał formy liter. Wprost odwrotnie - podłoże interaktywnie oddziaływało na ich kształty, poddając się naciskowi stylosa, który zostawiał w nim żłobienia. W ten sposób rylec i wosk interaktywnie współuczestniczyły w przekształcaniu ,subiektywnego ducha” myśli w „obiektywnego ducha” pisma. Dopiero więc po takim uwzględnieniu narzędziowego aspektu modelu etycznego Viléma Flussera można wyjaśnić mechanizm nadawania piśmiennej wartości rytom oznaczającym głagolickie litery. Potwierdza to myśl Tima Ingolda: „nie tyle chodzi o narzucenie bezwładnej materii wymyślonych wcześniej form, ile o interweniowanie w pola sił i prądy materiału, w których rodzą się formy" (Ingold, 2018, 123).

\section{Afordancje materiałowe a piśmienna praxis}

Mając na uwadze powyższe modele, można na koniec spróbować pokazać, w jaki sposób afordancje wosku mogły aktywnie wpłynąć na fizyczne formowanie głagolicy. Niezależnie bowiem od tego, jak Cyryl abstrakcyjnie wykoncypował w swym umyśle jej litery, musiał on potem realnie wypracować ich kształty na materiale piśmiennym. Było to niezbędne dla optymalizacji ich formy, a także wyćwiczenia mikromotoryki dłoni posługującej się rylcem w nowy sposób. Praktyka piśmienna podpowiadała mu, 
że najlepiej nadawało się do tego woskowe podłoże, które nie stawiało oporu rylcowi, umożliwiając swobodny ruch ręki. Przyczyną nie były tu więc namysł i kalkulacja, lecz działanie prowadzące do uzyskania najlepszego rezultatu podjętej czynności. Pragmatyka taka wpisuje się w ogólną refleksję Otla Aichera o wzorowanej na przyrodzie projektowej naturze kultury:

To, co się sprawdziło, to, co się potwierdziło w użyciu, jest zasadą doboru form egzystencji. Rozwojem świata nie kieruje jakiś określony rozum jako zasada sprawcza, jego droga jest ustalana przez zasadę wyboru tego, co efektywniejsze. Tak jak każdy daje sobie radę we wzajemnych relacjach $\mathrm{z}$ innym $\mathrm{i}$ innymi (Aicher, 2016, 202).

Odnosząc to do kształtowania przez Cyryla na wosku głagolickich liter, można zatem powiedzieć, że dokonał on tego, stosując swoisty „dobór naturalny" ich kształtów, konfrontując swój zamysł z materiałowymi uwarunkowaniami procesu pisania. W tym celu rzeczywiście mógł on posłużyć się woskowymi tabliczkami i brązowym rylcem, gdyż pozwalały one swobodnie nanosić korekty, usuwać spłaszczonym zakończeniem niesatysfakcjonujące znaki i ponownie wykreślać ostrzem piszącym ich poprawione postaci. Jeśli tak się stało, to afordancje pisarskie tych przyborów brały się z właściwości wykorzystanych w ich produkcji materiałów. W odniesieniu do pszczelego wosku była to jego miękkość i plastyczność, zaś w wypadku brązu - twardość i trwałość. W dłoni Cyryla przeciwstawne właściwości obu tych narzędzi wzajemnie by się wówczas warunkowały, stając się czynnikami współkształtującymi rzeczową postać słowiańskiego pisma.

W przeważającej mierze wynikało to $\mathrm{z}$ chemicznych i fizycznych cech pszczelego wosku, który w pokojowej temperaturze jest ciałem stałym, a więc wyryty na nim ślad pozostaje trwały i widoczny. W skład tego materiału wchodzi kilkanaście rożnych związków, głównie z trzech grup: wysokocząsteczkowych węglowodorów, wolnych kwasów tłuszczowych i estrów. Ich substancjalne połączenia sprawiają, że fizycznie wosk stanowi plastyczny materiał o charakterystycznym, drobnoziarnistym przełomie muszlowym. Twardość wosku jest dość zróżnicowana i obecnie określa się ją w sekundach potrzebnych do pogrążenia w nim na głębokość $1 \mathrm{~mm}$ igły specjalnego przyrządu, poddanej mierzalnemu naciskowi. Dla wosku tradycyjnie wytapianego w topiarkach słonecznych współczynnik ten wynosi 8-13 i jest znacząco wyższy od bardziej miękkiego surowca 
uzyskiwanego współczesnymi metodami ekstrakcji i wyciskania (Walewska, 1960, 261-262).

Parametr twardości w wypadku tego materiału piśmiennego jest ważny, gdyż wosk mniej poddający się naciskowi rylca stabilizował jego ruchy, co ułatwiało precyzyjne rycie żłobin. Ich głębokość, a więc wyrazistość śladu narzędzia, zależała zaś od siły presji dłoni oraz od grubości reaktywnej warstwy podłoża. Mogła być ona różna w zależności od tabliczki, jaką posługiwał się piszący, i jej indywidualnych cech konstrukcyjnych. Zasadniczo określała ją bowiem wysokości ramki powstającej w wyniku wydłutowania drewna w środkowej części tabliczki. Tak utworzoną płycinę łatwo było zalać płynnym woskiem, gdyż topi się on już w stosunkowo niskiej temperaturze od $61-64,5^{\circ} \mathrm{C}$ (Walewska, 1960, 262). Wszystkie te właściwości sprawiały, że materiałem tym można było swobodnie manipulować, zmieniając jego cechy użytkowe zależnie od pisarskich potrzeb i upodobań.

Wydaje się, że właśnie owa zdolność wosku do łatwej mechanicznej i termicznej transformacji stała się dla Cyryla jedną z najistotniejszych zalet tego podłoża i być może skłoniła go do sięgnięcia po tabliczki i rylec jako narzędzia tworzenia słowiańskiego alfabetu. Pewną rolę mogła w tym odegrać konieczność wyćwiczenia nowych mikroruchów palców, co było niezbędne w posługiwaniu się nowym pismem, które dobrze było ćwiczyć na miękkim i podatnym materiale. Wosk pozwalał bowiem na swobodne rycie liter o krągłym kształcie, charakterystycznym wszak dla głagolickiego alfabetu, który powstał na planie rozety (Čunčić, 2012, 1-4). Zważywszy zaś, że ręka Cyryla nawykła była do bardziej kanciastej greckiej majuskuły, ułatwiało to formowanie piśmiennych znaków, wyrabiając zarazem pożądaną dla nich płynność pisarskiego gestu. Było to ważne, zwłaszcza że następnym krokiem miało stać się przeniesienie wyćwiczonego na wosku pisma na docelowy materiał, jakim był pergamin, na którym pisało się wówczas piórem o miękkiej końcówce wytwarzanym z ptasich lotek.

Można zatem przyjąć, że wykorzystywane do tworzenia liter głagolicy afordancje wosku mogły okazać się pomocne również w próbach ciągłego już pisania nowym alfabetem. Chociaż głagolickie pismo nie wymagało zmiany chwytu pisarskiego rylca ani ptasiego pióra, to jednak konieczne było nabycie przez piszącego nowej mikromotoryki dłoni niezakorzenionej uprzednio w pamięci nawykowej, która jest rodzajem pamięci proceduralnej (Zimbardo, 1999, 354). Jej zyskanie jest niezbędne do sprawnego 
władania przyborami piśmiennymi, gdyż tego rodzaju czynności wykonywane są nie tylko z udziałem świadomości, lecz w dużej mierze na podstawie automatyzmu wcześniej wyuczonych ruchów (Ramachandran, 2012, 303). Jak pisze bowiem Bjørnar Olsen (2013, 181): „W naszej «przeciętnej codzienności» powtarzamy pewne czynności z przyzwyczajenia lub jako «instrukcje» dla motorycznych zdolności, których dostarczają nam rzeczy”.

Możliwość wyćwiczenia na miękkim wosku mikroruchów palców $\mathrm{i}$ ich wykorzystywania $\mathrm{w}$ pisaniu wynikała więc $\mathrm{z}$ afordancji tego podłoża, które pozwalało nawykowo je zapamiętywać. W wielu aspektach przypominało to dokonaną przez Bjørnara Olsena „narzędziową” reinterpretację znanego przykładu organisty zasiadającego do nowego instrumentu, który Maurice Merleau-Ponty (2001, 166-167) przywołał dla objaśnienia pamięci nawykowej. Olsen podkreśla, że:

nie tylko wyćwiczone i zręczne stopy organisty są istotne. Jego umiejętność może okazać się użyteczna tylko we współdziałaniu z organami, które mają te same znane właściwości, co instrument, na którym organista uczył się grać - aby uczynić możliwym zaktualizowanie i pamiętanie tej czynności (Olsen, 2013, 188).

Tak samo działo się w wypadku posługiwania się przez Cyryla pergaminową kartą. Liczyły się wówczas nie tylko zręczne palce, lecz także miękkie pióro z ptasich lotek, którego mikroruchy można było szybko opanować, odwołując się do pamięci nawykowej wyrobionej na łatwo poddającym się naciskowi rylca wosku. Jego piśmienne właściwości sprawiały zatem, że wyuczone umiejętności przeniesione na pergamin automatycznie aktualizowały się na nowym materiale.

Warto w tym miejscu nadmienić, że użytek pszczelego wosku do wypracowywania liter głagolickich pisma nie kłóci się z faktem, że było ono tworzone na potrzebę tłumaczenia Ewangelii na język słowiański, a więc dla celów sakralnych. Wymagało to sięgnięcia po szlachetny materiał, którym był nie tylko pergamin, lecz także oczyszczony wosk, z którego wytwarzano świece wykorzystywane podczas celebrowania Bożej liturgii. Dość przypomnieć tu słowa św. Szymona (Symeona) z Salonik, który tak o tym nauczał w 134. rozdziale Świętych rytuałów i sakramentów Kościoła:

wosk zbierany z roztaczających woń kwiatów, oznacza łaskę Świętego Ducha; wosk, utworzony z wielu kwiatów, wyraża Ofiarę czynioną przez wszystkich chrześcijan; 
wosk jako tworzywo, które się spala, oznacza nasze przebóstwienie (czyli naszą naturę oczyszczoną przez ogień) (Patrologia Graeca, vol. 155, 134, cyt. za Nowe tablice, 2007, 43).

Konkludując, można zatem powiedzieć, że w metodologicznym ujęciu teorii ontologiczno-funkcjonalnej przybory i materiały pisarskie stawały się mediatorami pomiędzy kreatywną myślą św. Cyryla a jej przedmiotowym uobecnieniem. Nie tylko oddziaływały one na przebieg procesu kreacji pisma, lecz same ulegały w jego toku przemianom. W przestrzeni zmysłowego świata woskowe powierzchnie tabliczek dostosowywały mentalny projekt głagolicy do materiałowych uwarunkowań jego realizacji, fizycznie go modyfikując. Równocześnie taki ich użytek aktualizował ich afordancje, a przez to transformował ich narzędziowe funkcje. Pod wpływem obu tych procesów żłobiny w wosku przemieniały się w nieznane wcześniej litery, rylce stawały się narzędziami kształtującymi ich znaczące formy, zaś dłonie nabywały dodatkowych zdolności mikromotorycznych w interakcji z woskiem.

W wypadku głagolicy jej tworzenie było zatem zarówno procesem mentalnym, jak i fizycznym z udziałem przedmiotów takich jak woskowe tabliczki. Łatwość rycia na miękkim podłożu kształtów nowych liter i możliwość wielokrotnego ich zmazywania pozwalała św. Cyrylowi na eksperymentowanie $\mathrm{z}$ ich formami bez zużywania cennego pergaminu. Proces ten zależny był więc głównie od materiałowych właściwości wytwarzanego przez pszczoły miodne wosku, którym pokrywano przeznaczone do pisania rylcem drewniane tabliczki. W ten sposób owady te współuczestniczyły w tworzeniu materiałowego wymiaru słowiańskiego pisma, na równi z ludźmi, którzy przejmowali od nich pałeczkę, wybierając wosk z uli, by dalej go przetwarzać. Dowodzi to, że św. Cyryl nie wtłaczał powstałych w jego umyśle form głagolickich liter na bierny materiał, lecz że ukształtowane przez pszczoły piśmienne afordancje wosku aktywnie współdziałały w tym procesie.

\section{Literatura}

Aicher, O. (2016). Świat jako projekt. Przeł. R. Darda-Staab, I. Dębek. Red. nauk. pol. wyd. A. Siemes, M. Wszołek. Wrocław: Wydawnictwo Libron. 
Bischoff, B. (1990). Latin Palaeography. Antiquity \& the Middle Ages. Trans. D. O. Cróinin, D. Ganz. Cambridge: Cambridge University Press. https://doi.org/10.1017/ CBO9780511809927.

Bodei, R. (2016). O życiu rzeczy. Przeł. A. Bielak. Łódź: Wydawnictwo Przypis. Breasted, J. H. (1916). The Physical Processes of Writing in the Early Orient and Their Relation to the Origin of the Alphabet. „The American Journal of Semitic Languages and Literatures" vol. 32, no. 4, s. 230-249. https://doi.org/10.1086/369798.

Čunčić, M. (2012). Granice geometrije i simbolike u glagoljskoj paleografiji. „Slovo: časopis Staroslavenskoga instituta u Zagrebu". http://bib.irb.hr/datoteka/335643. Cuncic_Granice_geometrije_i_simbolike_u_glagoljskoj_paleografiji.pdf. 14.11.2020.

Czernorizec Chrabr (2013). O piśmie. Przeł. A. Naumow. W: Święci Konstantyn-Cyryl i Metody patroni Wschodu i Zachodu, t. I: Apostołowie Slowian w dawnej Europie. Oprac. zespół pod red. A. Naumowa. Kraków: Collegium Columbianum, s. 33-36. Dahl, S. (1965). Dzieje ksiązki. Przeł. A. Garbacik i in. Wrocław-Warszawa-Kraków: Zakład Narodowy im. Ossolińskich.

Dain, A. (1949). Les manuscrits. Paris: Les Belles-Lettres. https://doi.org/10.4000/books.lesbelleslettres.11395.

Engelmann, R. (1896). Hellada i Roma. Życie Greków i Rzymian, t. I. Przeł. S. Mieczyński. Warszawa: Nakładem Gebethnera i Wolffa.

Fawcet, N., Zietsman, J. (2001). Uluburun - The Discovery and Excavation of the World's Oldest Known Shipwreck. „Akroterion” no. 46, s. 5-20. https://doi. org/10.7445/46-0-116.

Flusser, V. (2018). Kultura pisma. Z filozofii słowa i obrazu. Przeł. i posłowiem opatrzył P. Wiatr. Warszawa: Wydawnictwo Aletheia.

Gadamer, H.-G. (1993). Prawda i metoda. Przeł. B. Baran. Kraków: inter esse.

Gekeler, W. (2014). Pszczoły. Poradnik hodowcy. Warszawa: Wydawnictwo RM.

Houston, K. (2017). Książka. Najpotężniejszy przedmiot naszych czasów zbadany od deski do deski. Przeł. P. Lipszyc. Kraków: Wydawnictwo Karakter.

Horodyński, B. (1951). Podręcznik paleografii ruskiej. Kraków: Wydawnictwo Studium Słowiańskiego Uniwersytetu Jagiellońskiego.

Ingold, T. (2018). Splatać otwarty świat. Wyb. i oprac. E. Klekot. Kraków: Instytut Architektury.

Jansen, M. S. (1980). The Homeric Question and the Oral-Formulaic Theory. Copenhagen: Museum Tusculanum Press.

Krąpiec, M. A. (1968). Materia i forma. Ich różne rozumienie $w$ historii filozofii. „Roczniki Filozoficzne” t. XVI, z. 1, s. 55-65.

Latour, B. (2010). Splatajac na nowo to, co spoleczne. Wprowadzenie do teorii aktora-sieci. Przeł. A. Derra, K. Abriszewski. Kraków: Universitas.

Merleau-Ponty, M. (2001). Fenomenologia percepcji. Przeł. M. Kowalka, J. Migasiński, posł. J. Migasiński. Warszawa: Fundacja Aletheia.

Noordzij, G. (2014). Kreska. Teoria pisma. Przeł. M. Komorowska. Kraków: d2d.pl.

Norman, D. (2018). Dizajn na co dzień. Przeł. D. Malina. Kraków: Karakter. 
Nowe tablice, czyli o cerkwi, liturgii, nabożenstwach $i$ utensyliach cerkiewnych. Objaśnienia Beniamina arcybiskupa Niżnego Nowogrodu i Arzamasy. Wybór. (2007). Przeł. I. Pietrov. Kraków: Wydawnictwo Uniwersytetu Jagiellońskiego.

Obolenski, D. (1971). Byzantine Commonwealth Culture and Slavs. Eastern Europe, 500-1453. New York: ACLS Humanities.

Olsen, B. (2013). W obronie rzeczy. Archeologia i ontologia przedmiotów. Przeł. B. Shallcross. Warszawa: Instytut Badań Literackich PAN.

Pietkiewicz, K. (2015). Paleografia ruska. Warszawa: DiG.

Ramachandran, V. S. (2012). Neuronauka o podstawach człowieczeństwa. Warszawa: Wydawnictwo Uniwersytetu Warszawskiego. https://doi.org/10.31338/ uw.9788323529507.

Reed, R. (1975). The Nature and Making Parchment. Leads: Elmete Press.

Roberts, C. H., Skeat, T. C. (1982). The Birth of the Codex. Oxford: Oxford University Press.

Roffet-Salque, M., Regert, M., Evershed, R. P. (2015). Widespread exploitation of the honeybee by early Neolithic farmers. „Nature” no. 527, s. 226-230. https://doi. org/10.1038/nature15757.

Rosińska, Z. (2020). Nie tylko to co racjonalne. Teksty z filozofii kultury. Warszawa: Oficyna Naukowa.

Sanford, M. T., Dietz, A. (1976). The Fine Structure of the Wax Gland of the Honey Bee (Apis mellifera). „Apidologie” no. 7 (3), s. 197-207. https://doi.org/10.1051/ apido:19760301.

Santifaller, L. (1953). Beiträge zur Geschichte der Beschreibstoffe im Mittelalter Mit Berücksichtigung der päpstlichen Kanzlei. Graz-Köln: Böhlaus Nachf.

Sławski, F. (1991). Święci Cyryl i Metody - życie i dzieło. W: Cyryl i Metody apostołowie i nauczyciele Stowian. Red. J.S. Gajek MIC, L. Górka SVD. Lublin: Redakcja Wydawnictw Kul, s. 23-34.

Small, J. P. (1997). Wax Tablets of the Mind. Cognitive studies of memory and literacy in classical antiquity. London-New York: Routledge.

Walewska, K. (1960). Wosk pszczeli. W: Stownik towaroznawczy, t. 9. Warszawa: Polskie Wydawnictwo Gospodarcze, s. 255-268.

Wolf, F. A. (1795). Prolegomena Ad Homerum: Sive De Operum Homericorum Prisca Et Genuina Forma Variisque Mutationibus Et Probabili Ratione Emendandi. Halis Saxonum: E. Libraria Orphanotrophei.

Wójtowicz, M. (2000). Początki pisma słowiańskiego. Poznań: Wydawnictwo Naukowe UAM.

Zimbardo, P. (1999). Psychologia i życie. Warszawa: PWN.

Джурова, А., (1997). Въведение в славянската кодикология. София: Център за славяно-византийски проучвания „Иван Дуйчев”.

[Dzhurova, A. (1997). Vavedenie v slavyanskata kodikologiya. Sofiya: Centar za slavyano-vizantiyski prouchvaniya „Ivan Duychev”]. 